\title{
Reducing Employee Turnover
}

\section{Pauline Blachford}

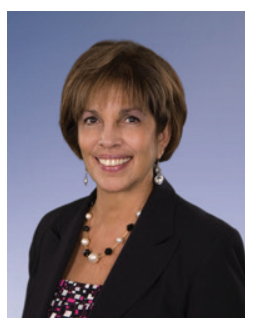

Pauline Blachford consults optometrists on how to reduce unbooked appointments, increase eyewear sales, and improve employee productivity. She has abundant experience in the eye health industry, including 17 years at White Rock Optometry in B.C. Pauline frequently presents at optometry conferences and is a regular columnist for the CJO. For more information, visit paulineblachford.com.

"Darn it! Another employee resignation, just when we were hitting our stride..."

I hear this all the time. Employee turnover is one of the most frustrating aspects of running a practice.

When an employee resigns, an optometrist has to sink scarce time and energy into finding a replacement. Meanwhile, the rest of the staff has to shoulder a heavier workload, and the departure decreases office morale.

It all costs you. Research has found that replacing an employee costs a business $150 \%$ of that employee's annual salary. ${ }^{1}$ This is, in part, due to the resources required to find and train a replacement.

To mitigate this impact, many employers scale back on the time, energy, and financial resources that they invest in their staff.

This approach is predicated on the assumptions that an employer cannot do anything to reduce employee turnover; that employees are bound to leave; and that investing in them through training or time will only increase what is already a costly process. Approaching the problem from this perspective considers employees as costs to be reduced and liabilities that must be hedged.

Research, however, shows that the opposite approach yields better results. Treating your staff as assets - ones that warrant significant and continual investment - reduces employee turnover. ${ }^{2}$ Moreover, this approach has shown to dramatically increase employee productivity, subsequently boosting the business's financial returns over the long run. ${ }^{3}$

In 2003, Bassi and McMurrer conducted a study in which they only invested in companies that aggressively invested in employee development. Two years later, their portfolio had outperformed the S\&P 500 index by $17-35 \%{ }^{4}$

As indicated by ample empirical evidence, as well as my two decades of experience working on the business side of optometry, here are three ways that I recommend you invest in your employees to reduce turnover while increasing productivity.

\section{RAMP UP COMMUNICATION}

In an adapted article from his book Leading with Trust is like Sailing Downwind, Robert T. Whipple states that in nearly every employee satisfaction survey he conducts, communication surfaces as a top issue. To address it efficiently and effectively, employers need to establish a constant, two-way flow of information with their employees. ${ }^{1}$

To open these channels of communication, try conducting an employee satisfaction survey. ${ }^{5}$ Also, hold weekly team meetings, ${ }^{6}$ and ask each employee to create a personal development plan. ${ }^{7}$ 
Admittedly, communicating with your employees and implementing their suggestions will take a lot of your time, but it is a small investment compared with the risks and costs involved in constantly having to hire and train new staff.

\section{INVEST IN TRAINING YOUR EMPLOYEES}

Investing in training your employees indicates that you view your team members as assets that you want to grow with you over the long term. It also provides your employees with career stimulation without their having to seek out new opportunities with a different company.

Optometry conferences are a good start and the Optometric Assistant Course offered by the Canadian Association of Optometrists (CAO) has four modules that will help your staff develop practical skills and knowledge. Bringing in the right optometry consultant will provide your employees with coaching that is tailored to their individual strengths and weaknesses and to your practice's unique goals.

You can also look outside the optometry sector. For example, offer to enroll one of your budding young employees in a social or digital media course, and then task her with website and social media responsibilities.

A common concern associated with paying for employees to receive training is that it may indirectly cause them to leave. While training will increase an employee's value within your practice, it will also increase their value in the job market.

Despite this, research supports training employees. A study that surveyed 2833 Dutch pharmacy assistants who were sent for training by their employers found that employees view skills training as a gift and that this increases their loyalty to their employer. Furthermore, the study found no evidence to support the theory that an employee's intention to quit is positively related to their participation in general training. ${ }^{2}$

\section{REWARD GOOD PERFORMANCE}

Rewarding good performance will give your most productive employees reason to stay with your practice.

You may choose to reward your employees in many ways. I believe that the most underrated form of recognition is a thank-you note or a thoughtful email that expresses appreciation for a particular act.

Another effective form of recognition is an incentive program. Whether they are trips, prizes, or cash, incentive programs keep employees engaged and excited about their work. ${ }^{1}$

A research report by the International Society of Performance Improvement found that reward programs can increase performance by an average of $22 \%$ and that team incentives can increase performance by up to $44 \%{ }^{3}$

A further benefit that is unique to incentive programs is that unlike most investments, you do not have to pay into an incentive program unless you receive the desired returns.

Design, however, is key. Individualized incentive programs can introduce counterproductive competitiveness among your team, and group incentive programs can cause resentment if the team perceives certain employees to be freeloading.

To avoid these pitfalls, have your employees assist you in designing the program from the outset, and check in regularly to ensure that the program is having its desired effects.

Inevitably, employee turnover will happen. But you can significantly reduce the rate at which it occurs by treating your employees as assets and investing in them accordingly. Doing so will improve the morale at your practice as well as your bottom line. 
I am currently conducting research for an article on how to grow your client base, which will be published in an upcoming issue of the CJO. Do you have any questions or recommendations related to this topic? If so, please contact me at info@paulineblachford.com.

\section{REFERENCES}

1. Whipple RT. 10 Keys for reducing turnover. Leadergrow Inc. 2010; www.leadergrow.com.

5. Check out some of the demos on this website: http:// www.hr-survey.com/EmployeeOpinion.htm.

2. Koster F, et al. Does perceived support in employee development affect personnel turnover? Int J Hum Resource Manage 2011;22(11): 2403-18.

3. Smith MM. Building the business case for investing in employees. Compensation Benefits Rev 2013;44(6):327331.

4. Bassi L, McMurrer D. How's your return on people? Harvard Business Rev 2009;18.

6. 100 Ideas to engage \& retain employees. HR insights blog. http://www.yourerc.com/blog/post/100-Ideas-toEngage-Retain-Employees.aspx. (See recommendations $5,16,60$ and 98).

7. Heathfield SM. Steps to Create a Career Development Plan. About Money Blog. http://humanresources.about. com/od/careersuccess/qt/steps-to-create-a-careerdevelopment-plan.htm.

\section{Optimize your investment!}

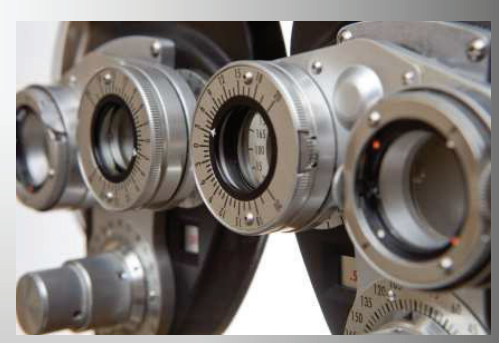

Visit us at (www.proptix.com) for the full range of instrument we cover.

Quick turn-around, warranty, $100 \%$ satis faction, competitive rate, Free loaner

GET EXTRA $10 \%$ OFF BY USING CODE: CJO2014

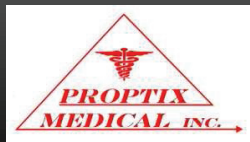

Proptix Medical Inc.

www. poptix.com

(416) $848-4577$

866)379-6560 